Jurnal Sastra Indonesia

http://journal.unnes.ac.id/sju/index.php/jsi

\title{
NILAI MORAL DALAM CERITA RAKYAT PESISIRAN \\ SEBAGAI ALTERNATIF BAHAN AJAR
}

\section{Zuliyanti $^{\bowtie}$, Nurul Fitrotul}

Jurusan Bahasa dan Sastra Indonesia, Fakultas Bahasa dan Seni, Universitas Negeri Semarang, Indonesia

\section{Info Artikel}

Sejarah Artikel:

Diterima Juli 2018

Disetujui September 2018

Dipublikasikan November 2018

\section{Keywords:}

Moral values, coastal

folklore, teaching

materials, old literary

history

\begin{abstract}
Abstrak
Tujuan penelitian ini adalah mendeskripsikan analisis nilai-nilai moral dalam cerita rakyat pesisiran sebagai alternatif bahan ajar dalam pembelajaran Sejarah Sastra Lama. Metode penelitian ini digunakan metode analisis deskriptif kualitatif. Objek penelitian ini adalah cerita rakyat pesisiran. Sumber data penelitian ini adalah masyarakat pesisiran yang memahami cerita rakyat pesisiran. Teknik pengumpulan data penelitian ini adalah studi pustaka, teknik observasi, teknik wawancara, dan teknik simak catat. Sedangkan instrumen penelitian ini adalah lembar observasi, lembar wawancara, dan kartu data. Teknik analisis data dilakukan dengan tahap-tahap: (1) pengumpulan data, (2) reduksi data, (3) penyajian (display) data, dan (4) penyimpulan atau verifikasi data dan hasil. Hasil penelitian diketahui bahwa cerita rakyat dari pesisiran terkandung nilai sosial dan agama yang dapat diterapkan dalam kehidupan sehari-hari dan dijadikan teladan dalam menjaga kerukunan dan ketentraman. Nilai-nilai sosial dan agama tersebut sangat cocok untuk diintegrasikan dalam pembelajaran sastra terutama dalam pembelajaran Sejarah Sastra Lama.
\end{abstract}

\begin{abstract}
The purpose of this study is to describe the analysis of moral values in coastal folklore as an alternative teaching material in learning the History of Old Literature. This research method used qualitative descriptive analysis method. The object of this research is coastal folklore. The source of this research data is coastal communities that understand coastal folklore. The data collection techniques of this study are literature studies, observation techniques, interview techniques, and note taking techniques. While the research instruments are observation sheets, interview sheets, and data cards. Data analysis techniques are carried out with stages: (1) data collection, (2) data reduction, (3) data presentation (display), and (4) inference or verification of data and results. The results of the study show that folklore from coastal areas contains social and religious values that can be applied in daily life and are exemplary in maintaining harmony and tranquility. These social and religious values are very suitable to be integrated in literary learning, especially in learning the History of Old Literature.
\end{abstract}

(C) 2018 Universitas Negeri Semarang

\footnotetext{
$\triangle$ Alamat korespondensi:

Gedung B1 Lantai 1 FBS Unnes

Kampus Sekaran, Gunungpati, Semarang, 50229

E-mail: zuliyanti@mail.unnes.ac.id
}

ISSN 2252-6315 


\section{PENDAHULUAN}

Karya sastra hadir sebagai gambaran kehidupan lengkap dengan segenap budayanya yang kompleks dengan nilai-nilai moral kehidupan di dalamnya. Selain berfungsi sebagai hiburan, karya sastra juga dapat menjadi sarana untuk menanamkan nilai-nilai moral bagi pembacanya. Keberadaan nilai moral dalam sastra diharapkan mampu memunculkan nilainilai positif bagi pembaca, sehingga mereka peka terhadap masalah-masalah yang berkaitan dengan kehidupan sosial dan mendorong untuk berperilaku baik (Hidayah, Ghazali, dan Roekhan 2012).

Karya sastra dapat memainkan peranannya sebagai media komunikasi dalam menyampaikan aturan tentang nilai-nilai moral kepada para pembacanya baik anak-anak, remaja, maupun orang dewasa. Kajian sastra aliran moralisme tidak terbatas hanya pada satu genre sastra, melainkan bersifat absolut. Kajian sastra moralisme dapat diimplementasikan pada cerpen, novel, sajak, pantun, dan cerita rakyat. Karya-karya tersebut penting untuk dibaca, dipelajari serta dikaji untuk memaksimalkan fungsi dan perannya dalam menyampaikan nilai-nilai moral terutama bagi generasi muda.

Peran sastra yang sangat strategis dapat dijadikan sebagai sarana yang mujarab dalam mengenalkan budaya dan nilai-nilai kehidupan dengan mengintegrasikannya dalam pembelajaran pada tiap-tiap jenjang pendidikan. Salah satunya dalam pembelajaran sastra yang sangat potensial untuk mengajarkan karya-karya sastra dari nusantara seperti cerita rakyat. Cerita rakyat adalah karya sastra yang menarik untuk dipelajari dan dikenalkan kepada generasi muda karena sekaligus mengenalkan budaya daerah.

Cerita rakyat adalah beberapa bagian dari tradisi lisan yang hidup dalam suatu daerah yang kini hampir punah (Gusal, 2015). Kepunahan cerita rakyat bisa saja terjadi manakala tidak ada yang mempelajari dan mewariskannya. Kondisi ini tergambar pada sebagian besar generasi muda yang minim informasi berkaitan dengan cerita rakyat di daerahnya terutama di daerah pesisiran, yaitu Demak, Kudus, Jepara, dan sekitarnya.

Cerita rakyat pesisiran adalah kekayaan budaya yang sudah seharusnya dilestarikan. Namun sayangnya, cerita rakyat tersebut masih belum populer di masyarakatnya sendiri. Ketidakpopuleran cerita rakyat tampak pada minimnya pemanfaatannya dalam pembelajaran terutama pembelajaran sejarah sastra lama. Hal tersebut berpijak pada capaian pembelajaran sejarah sastra lama yang mengkaji sastra lama, salah satunya adalah cerita rakyat.

Berpijak pada pentingnya mempelajari dan mewariskan sastra terutama cerita rakyat pesisiran, maka perlu optimalisasi penggunaan cerita rakyat sebagai bahan ajar dalam pembelajaran Sejarah Sastra Lama. Penguatan tersebut dapat dilakukan dengan pemanfaatan dan pengoptimalan bahan ajar yaitu cerita rakyat pesisiran sebagai kajiannya. Cerita rakyat yang dikaji dan dijadikan bahan ajar pembelajaran tersebut sangat tepat apabila dikaji mendalam dengan dianalisis muatan nilai-nilai moralnya agar dapat dioptimalkan dalam menguatkan karakter humanis bagi mahasiswa. Dengan demikian, dalam penelitian ini dibahas analisis nilai-nilai moral dalam cerita rakyat pesisiran sebagai alternatif bahan ajar dalam pembelajaran Sejarah Sastra Lama.

\section{METODE PENELITIAN}

Metode penelitian ini bersifat kualitatif dengan digunakan metode analisis deskriptif. Metode analisis digunakan dengan cara mencatat dan menganalisis cerita rakyat pesisiran. Langkah-langkah penelitian ini meliputi: (1) mengidentifikasi cerita rakyat pesisiran, (2) mencari dan mengumpulkan cerita rakyat pesisiran dari sumber primer maupun skunder di wilayah pesisiran, (3) menganalisis nilai-nilai moral dalam cerita rakyat pesisiran dan (4) menyusun laporan hasil penelitian.

Objek penelitian ini adalah cerita rakyat pesisiran. Adapun subjek penelitian ini adalah narasumber yang memahami cerita rakyat di daerah pesisiran. Sumber data penelitian ini adalah transkrip hasil wawancara dengan masyarakat pesisiran yang memahami cerita rakyat pesisiran sebagai alternatif bahan ajar dalam pembelajaran Sejarah Sastra Lama. Teknik pengumpulan data penelitian ini dilakukan dengan cara melakukan studi pustaka, teknik observasi, teknik wawancara, dan teknik simak catat. Sedangkan instrumen penelitian ini adalah lembar observasi, lembar wawancara, dan kartu data. Setelah menemukan, merumuskan, dan menganalisis cerita rakyat pesisiran, selanjutnya mengaitkan nilai-nilai moral tersebut sebagai alternatif bahan ajar dalam pembelajaran Sejarah Sastra Lama.

Pada tahap analisis dan interpretasi data, dilakukan analisis terhadap data-data yang telah ditetapkan dengan menggunakan pendekatan deskriptif kualitatif. Secara umum analisis data berdasar pada langkah-langkah yang dikemukakan Miles dan Huberman (dalam 
Koentjoro 2002), yang meliputi tahap-tahap: (1) pengumpulan data, (2) reduksi data, yaitu mereduksi (membuang) data-data yang dirasa tidak relevan untuk kepentingan penelitian, (3) penyajian (display) data, berupa klasifikasi, penampilan, uraian, deskripsi, dan sebagainya, dan (4) penyimpulan atau verifikasi data dan hasil.

\section{HASIL PENELITIAN}

\section{Analisis Nilai Moral Cerita Rakyat Pesisiran}

Cerita rakyat pesisiran yang dijadikan subjek dalam penelitian ini adalah cerita rakyat dari Kabupaten Kudus, Demak, dan Jepara. Cerita rakyat tersebut sarat dengan nilai-nilai luhur yang disampaikan oleh nenek moyang kepada generasi berikutnya. Berikut hasil analisis nilai-nilai moral cerita rakyat pesisiran.

\section{Asal Usul Desa Jember}

Pada cerita rakyat yang berjudul Asal Usul Desa Jember. Nilai-nilai yang terkandung dalam cerita rakyat tersebut yakni nilai budaya dan nilai sosial. Nilai budaya yang terdapat pada cerita rakyat berjudul Asal Usul Desa Jember. Nilai budaya yang terdapat dalam cerita rakyat tersebut yakni kegemaran menyabung ayam yang dilakukan oleh masyarakat Kedu. Hal itu dapat dibuktikan pada kutipan teks yakni sebagai berikut.

Melalui karaktristik masyarakat Kedu yang gemar menyabung ayam maka putra Sunan Kudus mendekati mereka dengan pendekatan sosio kultural yakni dengan mengikuti sabung ayam tersebut dan pertandingan tersebut mengantarkan pada kemenangan dari putra Sunan Kudus.

Selain nilai budaya yang terdapat dalam cerita rakyat tersebut, terdapat pula nilai sosial. Nilai sosial yang terdapat dalam cerita rakyat berjudul Asal Usul Desa Jember dicontohkan oleh Sunan Kedu yang memiliki sifat lapang dada untuk mengakui kesalahan. Hal itu dapat dibuktikan pada kutipan sebagai berikut.

Melalui kejadian-kejadian tersebut Sunan Kedu mengakui kehebatan karomah Sunan Kudus, sehingga dia berniat untuk bai'at menjadi murid Sunan Kudus yang pada kala itu menjadi Manggoloyudo Kadipaten Demak Bintoro dan pada akhirnya kemudian berguru kepada Sunan Kudus.

Tidak hanya nilai sosial dan nilai budaya yang terdapat pada cerita rakyat yang berjudul Asal Usul Desa Jember tetapi juga nilai agama. Nilai agama yang terdapat pada cerita rakyat tersebut yakni sifat Sunan Kudus yang taat beragama. Ketaatan yang dilakukan oleh Sunan Kudus salah satunya yakni berdzikir setelah salat. Hal itu dapat dibuktikan pada kutipan sebagai berikut.

Sunan Kudus belum keluar dari masjid, beliau masih membaca dzikir seusai salat.

Dengan demikian, dapat disimpulkan bahwa nilai-nilai budaya dan sosial. Nilai budaya tersebut adalah budaya menyabung ayam yang dilakukan oleh masyarakat Kedu yang menjadikan seluruh masyarakat Kedu menjadi lebih dekat dan rukun. Nilai sosial yang muncul dari cerita ini adalah Sunan Kedu yang memiliki sifat lapang dada untuk mengakui kesalahan. Nilai agama yang terdapat pada cerita rakyat tersebut yakni sifat Sunan Kudus yang taat beragama. Ketaatan yang dilakukan oleh Sunan Kudus salah satunya yakni berdzikir setelah salat.

\section{Asal Usul Dukuh Sumber dan Bulusan}

Pada cerita rakyat Kudus yang berjudul Asal Usul Nama Dukuh Sumber dan Bulusan terdapat nilai agama dan nilai sosial. Nilai agama yang terdapat pada cerita rakyat tersebut yakni sikap positif yang ditunjukkan oleh Sunan Muria sebagi tokoh agama yakni Sunan Muria ketika Nuzulul Quran selalu bersilaturrahmi dan membaca Al-quran bersama sahabatnya. Sikap tersebut dapat dibuktikan pada kutipan cerita sebagai berikut.

Pada Bulan Ramadhan, tepatnya pada waktu malam Nuzulul Quran, Sunan Muria datang untuk bersilaturrahim dan membaca Al Quran bersama Mbah Dudo, sahabatnya.

Selain nilai agama terdapat pula nilai sosial, nilai sosial yang terdapat pada cerita rakyat berjudul Asal Usul Nama Dukuh Sumber dan Bulusan yakni sikap Mbah Dudo, sahabat Sunan Muria yang meminta maaf kepada Sunan Muria atas perilaku kurang baik yang dilakukan oleh kedua muridnya. Sikap positif yang ditunjukkan oleh Mbah Dudo tersebut terdapat pada kutipan berikut ini.

Mbah Dudo datang meminta maaf atas kesalahan kedua santrinya kepada Sunan Muria. Namun nasi sudah menjadi bubur, Umara dan Umari sudah menjadi bulus dan tidak mungkin dapat kembali lagi berubah menjadi manusia.

Berdasarkan uraian tersebut dapat disimpulkan bahwa cerita tersebut mengandung nilai agama yang sikap positif yang ditunjukkan 
oleh Sunan Muria sebagai tokoh agama yakni Sunan Muria ketika Nuzulul Quran selalu bersilaturrahmi dan membaca Al-quran bersama sahabatnya. Selain itu, nilai sosial dalam cerita tersebut adalah sikap untuk selalu meminta maaf apabila melakukan kesalahan.

\section{Asal Usul Desa Mlati}

Nilai-nilai yang terdapat pada cerita rakyat yang berjudul Asal Usul Desa Mlati yakni nilai agama dan nilai sosial. Nilai agama yang terdapat pada cerita rakyat tersebut yakni ditunjukkan sifat tekun beribadah Sunan Kudus. Sifat tekun beribadah Sunan Kudus yakni Sunan Kudus tetap melaksanakan salat Subuh di tepi sungai ketika mencari obat untuk para santrinya yang terkena penyakit kulit. Pada kondisi dan keadaan apapun, Sunan Kudus selalu tekun beribadah dan tidak melakukan Tuhan. Sifat tekun beribadah Sunan Kudus tersebut dapat dibutktikan pada kutipan sebagai berikut.

Saat Sunan Kudus beristirahat usai menunaikan ibadah sholat Subuh di tepi sungai sebelah timur pesantrennya, tiba-tiba tercium aroma yang sangat wangi.

Selain nilai agama, pada cerita rakyat yang berasal dari Mlati tersebut juga terdapat nilai-nilai sosial. Nilai sosial yang terdapat pada cerita rakyat Asal Usul Desa Mlati tersebut yakni sikap Sunan Kudus yang bertanggung jawab dan sabar. Sikap bertanggung awab tersebut terbukti ketika Sunan Kudus bersedia untuk mencari obat penyembuh bagi para santrinya yang terkena penyakit kulit. Sunan Kudus berperilaku sabar ketika selama melakukan pencarian mengalami hambatan dan rintangan. Sikap bertanggung jawab serta sabar yang dimiliki oleh Sunan Kudus tersebut terbukti pada kutipan teks cerita rakyat sebagai berikut.

Sunan Kudus akan sebuah bunga yang dapat menyembuhkan penyakit kulit yang saat itu tengah merebak dan menjangkiti para santri yang bermukim di padepokan atau pesantrennya Sunan Kudus. Sunan Kudus lalu melanjutkan perjalanan ke arah timur, beberapa saat kemudian, sampailah Sunan Kudus tiba di suatu desa yang banyak ditumbuhi tanaman bunga berwarna putih dengan bau yang harum. Setelah memetik beberapa tangkai Mlati, Sunan Kudus pun minta izin pulang kembali ke padepokannya. Betul juga, sesampainya di padepokan, ternyata setelah diolesi ramuan obat dengan bahan dasar tanaman tersebut penyakit kulit yang diderita para santrinya berangsur-angsur hilang, dan akhirnya para santrinya pun sembuh dari sakitnya.
Nilai sosial yang terdapat pada cerita rakyat Asal Usul Desa Mlati tidak hanya terdapat pada tokoh Sunan Kudus sebagai tokoh utama tetapi juga warga desa. Warga desa Mlati yang murah hati karena telah memberikan bunga melati dengan suka rela kepada Sunan Kudus dengan harapan bahwa para santri atau muris dari Sunan Kudus dapat sembuh dari penyakit kulit. Kutipan teks pada cerita rakyat tersebut dapat dibuktikan sebagai berikut.

"Boleh ki sanak, silahkan ambil sebanyak yang ki sanak butuhkan," jawab laki-laki tua itu sambil mempersilahkan Sunan Kudus mengambil beberapa tangkai tanaman miliknya.

Berdasarkan analisis tersebut dapat disimpulkan bahwa nilai yang terkandung dalam cerita tersebut adalah nilai agama dan sosial. Nilai agama dalam cerita tersebut tercermin dari sikap Sunan Kudus yaitu sikap tekun beribadah. Selain itu, nilai sosial yang terkandung adalah sikap bertanggung jawab dan sabar.

\section{Sayembara Putri Narayana}

Cerita rakyat yang berjudul Sayembara Putri Narayana karya mengandung nilai-nilai kehidupan yang dapat diaplikasikan dalam kehidupan sehari-hari. Nilai-nilai kehidupan yang terdapat pada cerita rakyat tersebut yakni nilai sosial. Nilai sosial tersebut yakni tampak pada karakter Sunan Muria yang memiliki kepibadian atau sifat suka menolong, tekun beribadah, dan jujur.

Sifat suka menolong Sunan Muria yakni ketika seorang penduduk datang menemui Sunan Muria untuk meminta pertolongan, maka saat itupula Sunan Muria memberikan pertolongan tanpa meminta imbalan. Sifat penolong tersebut dapat dibuktikan dalam kutipan teks sebagai berikut.

"Kanjeng Sunan, tolonglah kami agar kami tidak berlarur-larut dalam kesengsaraan," kata seorang penduduk dihadapan Sunan Muria yang ikut bersedih hati mendengar peristiwa itu.

Ketekunan Sunan Muria dalam beribadah Sunan Muria dan selalu bergantung pada Tuhan ditunjukkan pada teks yakni Sunan Muria bertafakur dan bersemedi untuk memohon kekuatan kepada Tuhan agar dapat mencapai tujuan. Kutipan teks cerita rakyat yang berjudul Sayembara Putri Narayana yakni sebagai berikut.

Setelah bertafakur atau bersemedi untuk memohon kekuatan kepada Tuhan, berangkatlah 
Sunan Muria ke Juwana bersama sejumlah santri dan para pengungsi.

Kejujuran Sunan Muria dapat diketahui yakni ketika Sunan Muria mengatakan dengan jujur bahwa Maling Kopo telah membantu Sunan Muria untuk mengalahkan Prabu Patak Warak, sehingga ia berhak mendapatkan sebagian bumi Juwana untuk membangun kehidupannya yang damai. Hal itu dapat dibuktikan melalui kutipan teks sebagai berikut.

Sunan Muria mengatakan dengan sejujurnya apa yang telah terjadi sambil menegaskan bahwa Maling Kopo berhak menerima sebagian bumi Juwana untuk membangun kehidupannya yang damai.

Selain Sunan Muria yang memiliki kepribadian baik pada cerita rakyat tersebut, terdapat pula tokoh Sunan Ngerang yang memiliki sifat menepati janji. Sunan Ngerang menepati janji kepada Sunan Muria sebagai seorang penduduk yang berhasil memenangkan sayembara. Sayembara dengan hadiah yakni sebuah pernikahan. Pernikahan yang dilakukan antara Sunan Muria dengan Putri Narayana, ptri dari Sunan Ngerang. Sifat Sunan Ngerang tersebut terdapat pada kutian teks yakni sebagai berikut.

Setelah urusan itu
terselesaikan maka Sunan
Ngerang pun memenuhi
janjinya untuk menikahkan
Putri Narayana dengan Sunan
Muria sebagai sang pemenang.

Kepribadian luhur yang ditunjukkan dalam cerita rakyat tersebut diketahui pula melalui karakter tokoh Maling Kopo. Maling Kopo merupakan kawan Sunan Muria telah membantu Sunan Muria untuk mengalahkan Prabu Patak Warak di laut. Pada cerita rakyat tersebut, maka Maling Kopo memiliki kepribadian suka menolong. Hal itu dapat diketahui pada kutipan teks cerita rakyat sebagai berikut.

Setelah beramah-tamah sebentar, berkatalah Sunan Muria, "Sahabtku yang sakti, kupanggil engkau dari kejauhan karena saat ini aku membutuhkan bantuannmu."

"Kakang Sunan, berbahagialah diriku sekiranya Kakang memerlukan tulang dan ototku yang kasar ini. Katakanlah, biar aku segera bisa bertindak."

Pisang Becici Pantang Dimakan
Pada cerita rakyat yang berjudul Pisang Becici Pantang Dimakan terdapat nilai-nilai kehidupan yang dapat diterapkan dalam kehidupan sehari-hari. Nilai-nilai kehidupan yang dapat diterapkan di antaranya nilai sosial dan nilai agama. Nilai sosial yang terdapat pada cerita rakyat tersebut dapat diketahui melalui kepribadian Sunan Muria dan sang Istri.

Kepribadian Sunan Muria yang terdapat pada cerita rakyat "Pisang Becici Pantang Dimakan" yakni perhatian kepada istri. Perhatian tersebut ditunjukkan oleh Sunan Muria kepada sang istri yakni ketika Putri Narayana menginginkan binatang rusa di masa kehamilan. Sunan Muria akhirnya mengambulkan permintaan tersebut dan memutuskan untuk berangkat ke hutan bersama para santrinya. Hal itu dapat dibuktikan pada kutipan sebagia berikut.

"Istriku, janganlah berkata demikian. Mana mungkin engkau sendiri pergi ke hutan. Bersabarlah, sekarang juga aku hendak pergi berburu. Berhati-hatilah di rumah sambil memohon kepada Allah agar dimudahkan jalanku."

Selain sifat perhatian yang dimiliki oleh Sunan Muria, terdapat pula sifat kepribadian sopan dan santun. Sifat sopan dan santun tersebut ditunjukkan dalam cerita rakyat karya tersebut yakni ketika Sunan Muria bertanya kepada seorang lelaki tua yang ditemui di dalam hutan. Kepribadian sopan dan santun tersebut dapat dibuktikan pada kutipan cerita rakyat sebagai berikut.

Pada akhir percakapan itu, berkatalah Sunan Muria dengan santun, "Ki Sanak, dapatkah engkau membantuku?"

"Alhamdulillah. Kalau memang demikian, marilah kita berkemas. Namun, kita harus berterima kasih lebih dahulu kepada Pak Tua yang telah mengantarku. Di manakah dia sekarang?"

Kepribadian sopan dan santun yang ditunjukkan oleh Sunan Muria juga dimiliki oleh tokoh laki-laki tua yang ditemui oleh Sunan Muria di hutan. Pertemuan tersebut berisi pembicaraan mengenai keberadaan rusa di dalam hutan. Lelaki Tua yang ditemui oleh Sunan Muria tersebut memberitahu Sunan Muria bahwa di sekitar hutan terdapat rusa yang ditinggalkan oleh pemiliknya. Lelaki tua tersebut memberitahukan kabar tersebut dengan sopan dan santun untuk menghargai Sunan Muria. Hal itu dapat diketahui melalui kutipan cerita rakyat "Pisang Becici Pantang Dimakan" yakni sebagai berikut. 
"Kanjeng Sunan, konon kabarnya hutan ini miliknya Lokajaya, seorang pendeta begawan yang sudah meninggalkan dunia. Sekiranya Kanjeng Sunan berkenan, sudilah meminta izin kepadanya. Hamba sendiri hanya dapat menunjukkan tempatnya bertapa, nanti Kanjeng Sunan yang harus menghadapnya."

Lelaki tua yang terdapat pada cerita tersebut tidak hanya meiliki kepribadian sopan dan santun tetapi juga penyabar. Kesabaran tersebut ditunjukkan ketika lelaki tua tersebut menjelaskan dengan hati-hati tanpa berkeluh kesah kepada Sunan Muria karena terlalu lama menunggu di gua. Kesabaran yang dimiliki oleh lelaki tua tersbut dapat diketahui melalui kutipan cerita rakyat sebagai berikut.

Sesampainya di gua pertapaan $K i$ Lokajaya, ternyata tak seorang pun yang dapat dijumpai Sunan Muria sehingga hampir saja timbul amarahnya. Namun, lelaki tua yang mengantarkannya segera berkata lembut, "Kanjeng Sunan, bersabarlah. Bukakah Allah sendiri mengajarkan kepada kita agar senantiasa bersabar?"

Tidak hanya Sunan Muria dan lelaki tua di dalam cerita rakyat "Pisang Becici Pantang Dimakan" yang memiliki kepribadian baik. Putri Narayana istri Sunan Muria juga memiliki kebribadian baik yang patut untuk diterapkan dalam kehidupan sosial masyarakat. Kepribadian Putri Narayana yang taat kepada suami di dalam cerita rakyat tersebut ditunjukkan melalui tindakan. Tindakan yang akhirnya dilaksanakan hingga sang suami, Sunan Muria menyelesaikan tugas.

Pada cerita rakyat tersebut, Putri Narayana mematuhi perintah Sunan Muria untuk menanti kepulangan Sunan Muria dari hutan dengan membawa rusa sebagaimana yang diinginkan oleh sang istri, Putri Narayana. Putri Narayana akhirnya menuruti dan berjanji bahwa ia akan setia menanti kepulangan sang suami yakni Sunan Muria. Hal tersebut dapat diketahui pada kutipan cerita rakyat sebagai berikut :

Jawaban Sunan Muria itu terdengar merdu di sanubari Putri Narayana, dan ia pun berjanji akan menanti dengan setia di pesantren.

Selain nilai sosial yang terdapat pada cerita rakyat berjudul Pisang Becici Pantang Dimakan, terdapat pula nilai agama. Nilai agama dalam cerita tersebut ditunjukkan melalui tokoh Sunan Muria. Sunan Muria sebagai tokoh agama memiliki peran penting dalam upaya penyebarana agama Islam di Kudus. Upaya tersebut ditunjukkan oleh Sunan Muria dan diterapkan dalam kehidupan sehari-hari. Ketaatan Sunan Muria sebagai tokoh agama pada cerita rakyat tersebut bahwa segala sesatu yang dilakukan oleh Sunan Muria dan keluarga selalu berdasar pada ajaran Tuhan. Tuhan adalah tempat manusia untuk memohon dan bergantung sehingga segala sesuatu hendaknya diserahkan kepada Tuhan setelah manusia berusaha dengan maksimal. Hal itu sebagaimana kutipan yang ditunjukkan dalam cerita rakyat tersebut yakni sebagai berikut.

"Istriku, janganlah berkata demikian. Mana mungkin engkau sendiri pergi ke hutan. Bersabarlah, sekarang juga aku hendak pergi berburu. Berhati-hatilah di ruamh sambil memohon kepada Allah agar dimudahkan jalanku."

"Alhamdulillah. Kalau memamng demikian, marilah kita berkemas. Namun, kita harus berterima kasih lebih dahulu kepada Pak Tua yang telah mengantarku. Di manakah dia sekarang ?"

Setelah merasa lelah dan sedih, Sunan Muria mengajak para santrinya beristirahat dan bersembahyang untuk memohon petunjuk dan kemudahan dari Allah SWT.

\section{Asal Usul Desa Pladen}

Cerira rakyat Kudus yang berjudul Asal Usuk Desa Pladen terdapat nilai-nilai kehidupan yang terdiri atas nilai agama dan nilai sosial. Nilai agama dan nilai sosial ditunjukkan oleh tokoh KRT Notokusumo.

KRT Notokusumo dalam kehidupan sehari-hari memiliki sifat tawadluk dan suka berdakwah untuk menyabarkan agama Islam. Sifat tawadluk dalam cerita rakyat tersebut yakni ketika KRT Notokusumo menghilangkan identitasnya sebagai seorang bangsawan dengan harapan ia dapat beribadah dengan khusuk. Kutipan teks cerita rakyat yang menunjukkan kepribadian KRT tersebut yakni :

Ketika beliau belajar mengaji di sana, beliau menghilangkan identitas bangsawanannya sebagai bukti sikap tawadluknya terhadap Sang Guru (selain untuk membuat musuhnya tidak kenal). Oleh karena hal tersebut, Sunan Muria memberikan nama baru yakni Samsudin Abdul Malik.

Selain memiliki pribadi tawadluk, KRT Notokusumo juga memiliki sifat suka berdakwah untuk menyebarkan agama Islam. Kegiatan dakwah tersebut dilakukan di sebelah utara wilayah dakwah kakak seperguruannya (Ki Anteng, cikal bakal Besa Bulung) untuk menunaikan tugas yang diberikan oleh Sunan Muria. Kegiatan dakwah tersebut, dalam cerita 
rakyat "Asal Usul Desa Pladen" dibuktikan dalam kutipan teks sebagai berikut.

Selesai nyantri dan menjadi pelayan (peladen) dengan Sunan Muria, KRT Notokusumo ditugaskan untuk berdakwah meng-Islamkan suatu tempat di sebelah tenggara Gunung Muria. Tempat tersebut berada di sebelah utara wilayah dakwah kakak seperguruannya (Ki Anteng, cikal bakal Besa Bulung).

Nilai sosial yang terdapat dalam cerita rakyat tersebut yakni kepribadian KRT Notokusumo yakni sabar dan bersungguhsungguh. Kesabaran dan kesungguhan KRT Notokusumo dintunjukkan ketika ia mengaji dengan Sunan Muria dan menjadi muridnya. KRT Notokusumo melakukan kegiatan tersebut dengan sabar dan bersungguh-sungguh. Hal itu dapat dibuktikan dalam kutipan teks cerita rakyat sebagai berikut.

KRT Notokusumo mengaji kepada

Sunan Muria dengan penuh kesabaran dan kesungguhan hati.

Selain itu, KRT Notokusumo juga memiliki sikap amanah atau dapat dipercaya. Sikap KRT Notokusumo yang dapat dipercaya tersebut ditunjukkan dalam cerita rakyat yakni ketika KRT Notokusumo menjadi santri abdi dalem untuk melayani Sunan Muria. Ia menjalankan amanah yang diberikan dan akhirnya KRT Notokusumo menjadi tangan kanan dari Sunan Muria. Hal itu dapat dibuktikan pada kutipan teks cerita rakyat yakni sebagai berikut.

Seiring berjalannya waktu, akhirnya KRT Notokusumo mendapatkan amanah dari gurunya untuk menjadi santri abdi dalem. Status tersebut, membuat beliau mempunyai kewajiban untuk melayani (ngladeni) keinginan dan kebutuhan Sunan Muria. Maka dapat dikatakan bahwa KRT Notokusumo merupakan "tangan kanan" yang selalu taat mendengar dan melaksanakan perintah sang guru.

\section{Asal Usul Sumur Bandungan}

Pada cerita rakyat berjudul Asal Usul Sumur Bandung di Desa Honggosoco terdapat nilai agama dan nilai sosial. Nilai agama yang terdapat pada cerita rakyat tersebut dapat dibuktikan melalui kepribadian Honggowongso. Honggowongso memiliki kepribadian taat beragama untuk menyebarkan agama Islam. Honggowongso melakukan babat alas dan mensyiarkan agama Islam karena perintah sang guru. Kegiatan tersebut dilakukan untuk mempermudah proses penyebaran agam Islam.
Hal itu ditunjukkan dalam kutipan teks cerita rakyat tersebut sebagai berikut.

Honggowongso melakukan babat alas dan mensyiarkan agama Islam, sebagaimana perintah Sang Guru di daerah ini. Hal yang dilakukan untuk memudahkan proses dakwahnya yakni ia membangun sebuah masjid di dekat tempat tinggalnya.

Selain nilai agama yang terdapat pada cerita rakyat "Asal Usul Sumur Bandung di Desa Honggosoco", terdapat pula nilai sosial. Nilai sosial yang terdapat pada cerita rakyat tersebut ditunjukkan oleh tokoh utama, Honggosoco. Honggowongso memiliki kepribadian suka menolong. Honggowongso memiliki kepribadian suka menolong. Hal itu sebagaimana yang terdapat dalam cerit arakyat tersebut yakni Honggowongso memberikan air sumur yang berada di dekat rumahnya untuk para warga sekitar agar dimanfaatkan untuk menyembuhkan penyakit. kepribadian Honggowongso tersebut dapat diketahui dalam kutipan teks cerita rakyat sebagai berikut.

Sumur tersebut kemudian digunakan oleh Honggowongso sebagai obat menyembuhkan penyakit warga sekitar. Popularitas sumur itu, mengundang banyak masyarakat untuk datang ke tempat Honggowongso dengan maksud berobat. Hal itu yang menyebabkan Honggowongso akhirnya membuat sebuah tempat pengobatan di dekat sumur tersebut.

\section{SIMPULAN}

Karya sastra hadir sebagai gambaran kehidupan yang lengkap dengan segenap budayanya dan nilai-nilai moral kehidupan di dalamnya sehingga efektif untuk diajarkan kepada para pembacanya. Karya sastra sangat strategis untuk dipelajari dalam pembelajaran sastra, seperti cerita rakyat pesisiran. Cerita rakyat pesisiran kaya akan budaya dan masih belum populer di masyarakatnya sendiri. Ketidakpopuleran tersebut tampak pada minimnya pemanfaatan cerita rakyat pesisiran sebagai bahan ajar terutama dalam pembelajaran sejarah sastra lama. Berpijak pada permasalahan tersebut, maka dapat dimanfaatkan dan dioptimalkan cerita rakyat pesisiran sebagai alternatif bahan ajar dalam pembelajaran Sejarah Sastra Lama.

\section{DAFTAR PUSTAKA}

Attas, Siti Gomo. 2015. "Pembelajaran Sastra Lisan: Upaya Pelestarian Mutiara yang Terlupakan". http://tigoattas.blogspot.co.id/2015/06 
/pembelajaran-sastra-lisan.html. Diunduh pada hari Rabu, 17 Februari 2016.

Azami, Yasin Syafii. 2014. "Nilai-Nilai Humanis dalam Karakter Tokoh Wayang Semar dan Relevansinya dengan Pendidikan Agama Islam". Skripsi. Yogyakarta: Universitas Islam Negeri Sunan Kalijaga.

Budiningsih, Asri C. 2010. "Strategi Pembelajaran Nilai yang Humanis". Dimuat dalam Majalah Ilmu Pendidikan Dinamika Pendidikan No.2/Th.XVII/Oktober 2010.

Danandjaya, J. 1985. Folklor Indonesia. Jakarta: Pustaka Utama Grafiti.

Gagne, E.D. 1985. The Cognitive Psychology of School Learning. Boston, Toronto:

Litle, Brown and Company.

Gusal, La Ode. 2015. "Nilai-Nilai Pendidikan dalam Cerita Rakyat Sulawesi Tenggara Karya La Ode Sidu". Dimuat dalam Jurnal Humanika No. 15, Vol. 3, Desember 2015.

Haerudin, Dingding. 2013. "Mengkaji NilaiNilai Moral Melalui Karya Sastra". Dimuat dalam Jurnal Pendidikan Bahasa dan Seni FPBS UPI.

Hidayah, Nur Kholis, A. Syukur Ghazali, Roekhan. 2012. "Nilai-Nilai Moral dalam Novel Negeri Lima Menara Karya A. Fuadi". Malang: Universitas Negeri Malang.

Magnis-Suseno, F. 2001. Kebangsaan yang humanis. Makalah Semnas. Yogyakarta: USD.

Mas'ud, Abdurrahman. 2004. Menggagas Format Pendidikan Nondikotomik, Humanisme Religius sebagai Paradigma Pendidikan. Yogyakarta: Gema Media.

Nuryatin, Agus, dkk. 2016. Buku Panduan Pilar Humanis Universitas Konservasi. Semarang: Unnes.

Rosmaya, Elin. 2013. "Penelitian Nilai Moral, Nilai Sosial, dan Nilai Budaya Pada Tiga Novel yang Difilmkan
Berdasarkan Pendekatan

Struktural dan Penerapannya untuk Penyusunan Bahan Ajar

Serta Kegiatan Pembelajaran Apresiasi Novel di SMA Islam Al Azhar". Dimuat dalam DEIKSIS Jurnal Pendidikan Bahasa dan Sastra Indonesia.

Setiartin, Titin R. 2016. "Transformasi Teks Cerita Rakyat ke dalam Bentuk Cerita Bergambar sebagai Model Pembelajaran Membaca Apresiatif". Dimuat dalam Jurnal LITERA, Volume 15, Nomor 2, Oktober 2016.

Simatupang, G. R. Lono Lastoro. 2011. "Penelitian Cerita Rakyat". Makalah disampaikan dalam Kegiatan Peningkatan Mutu Tenaga Teknis Balai Bahasa Yogyakarta, di Hotel University, Sleman, 2-3 November 2011.

Siregar, Eveline dan Hartini Nara. 2010. Teori Belajar dan Pembelajaran. Bogor: Ghalia Indonesia.

Thoha, Chabib. 1996. Kapita Selekta Pendidikan Islam. Yogyakarta: Pustaka Pelajar.

Thohiroh, Zulaifatut, U'um Qomariyah, dan Mukh Doyin. 2017. "Etika Humanisme dalam Cerita Rakyat di Kabupaten Jepara". Dimuat dalam Jurnal Sastra Indonesia Juli 2017. http://journal.unnes.ac.id/sju/index.ph p/jsi

Unsriana, Linda, "Nilai Kearifan Lokal Dalam Cerita Rakyat Jepang" (Minwa), Jurnal Humaniora, 4, no. 1 (2013): 310-317.

Wellek, Rene dan Austin Waren. 2014. Teori Kesusastraan. Jakarta: Gramedia. 